\title{
Determinasi Faktor-Faktor Ekonomi Pada Risiko Investasi Di Industri Pertanian
}

\author{
Ni Luh Anik Puspa Ningsih ${ }^{1 *}$, Made Pratiwi Dewi ${ }^{2}$, Ni Made Yuliati ${ }^{3}$ \\ Universitas Warmadewa
}

Korespondensi: kinapuspa168@gmail.com

\begin{abstract}
Abstrak
Industri pertanian merupakan salah satu sektor yang menopang perkembangan perekonomian serta memiliki tingkat pertumbuhan keluaran dan daya saing global komoditas pertanian yang potensial. Tujuan dari penelitian ini adalah untuk mengkaji hubungan faktor-faktor ekonomi terhadap risiko investasi di industri pertanian. Populasi dalam penelitian ini adalah perusahaan dalam industri pertanian yang terdaftar di Bursa Efek Indonesia periode 2014 - 2018 dan sampel yang terlobat dalam penelitian ini sebanyak 16 perusahaan. Penelitian ini berjenis kuantitatif, dengan menggunakan alat analisa regresi linier berganda, Dari hasil penelitian diketahui bahwa faktor ekonomi makro yang diwakili oleh tingkat suku bunga berpengaruh positif dan signifikan terhadap risiko investasi, sementara korelasi antara nilai tukar rupiah terhadap dollar amerika ditemukan negatif signifikan terhadap risiko investasi saham. Faktor ekonomi mikro yaitu struktur modal, ditemukan pola hubungan positif signifikan antara struktur modal dan risiko investasi, serta pola negatif tidak signifikan ditemukan dalam hubungan likuiditas terhadap risiko investasi di industri pertanian.
\end{abstract}

Kata Kunci : Struktur Modal, Likuiditas, Tingkat Suku Bunga, Nilai Tukar

\begin{abstract}
The agricultural industry is one of the sectors that sustain economic development and has a potential growth rate and global competitiveness of agricultural commodities. The purpose of this study is to examine the relationship of economic factors to the risk of investment in the agricultural industry. The population in this study were companies in the agricultural industry listed on the Indonesia Stock Exchange in the period 2014-2019 and the samples that were treated in this study were 16 companies. This research is a quantitative type, using multiple linear regression analysis. From the results of the study it is known that macroeconomic factors represented by interest rates have a positive and significant effect on investment risk, while the correlation between the rupiah exchange rate against the US dollar is found to be significantly negative on investment risk stock. Microeconomic factors, namely the capital structure, found a pattern of significant positive relationships between capital structure and investment risk, as well as a non-significant negative pattern found in the relationship of liquidity to the risk of investment in the agricultural industry.
\end{abstract}

Keywords: Capital Structure, Liquidity, Interest Rate, Exchange Rate

\section{A. PENDAHULUAN}

Sektor pertanian memiliki potensi sebagai penghasil komoditi ekspor nasional yang cukup potensial. BPS (2018) mencatat dalam perlambatan ekspor nasional, namun sektor pertanian mampu mencatat peningkatan sebesar $6.11 \%$ atau meningkat sebesar $7.38 \%$ dari tahun sebelumnya. Sumbangan sektor pertanian terhadap produk domestik bruto (PDB) nasional mengalami penurunan sejak awal tahun 2019. Kontrasnya, bursa efek indonesia mencatat indeks saham sektor ini masih memberikan return positif sebesar $1,79 \%$. Bahkan dalam top 10 besar saham emiten sektor ini menunjukkan nilai transaksi yang tinggi, mencapai 48 milyar rupiah. (www.idx.co.id, 2018)

Investasi pada sektor pertanian memiliki potensi cukup baik. Harga saham pada sektor pertanian tercatat mengalami peningkatan harga sebesar 2.87 poin dalam laporan harian perdagangan pada bursa efek indonesia. Rata-rata tingkat keuntungan yang diperoleh investor 
mencapai $3.58 \%$ per hari. Setiap keuntungan memiliki potensi risiko. Sektor pertanian memiliki potensi risiko yang harus dihadapi investor. Bursa mencatat kerugian (loss) yang dialami sektor pertanian rata-rata sebesar $2.26 \%$ per hari (idx quarterly statistic 4th quarter 2018)

Sesuai dalil high risk high return dijelaskan bahwa semakin tinggi tingkat risiko maka semakin besar tingkat keuntungan yang disyaratkan. Faktanya, investor menyukai risiko yang rendah dengan tingkat keuntungan yang optimal. Oleh karena itu investor harus mampu melakukan pengelolaan terhadap risiko. Analisa terhadap faktor yang berpengaruh terhadap risiko investasi penting dilakukan.

Secara umum risiko investasi dipengaruhi oleh faktor-faktor ekonomi makro dan mikro (Rizal, 2016). Faktor ekonomi makro diantaranya tingkat suku bunga dan nilai tukar (rupiah terhadap dolar Amerika). Faktor mikro yaitu struktur modal, tingkat likuditas perusahaan, leverage, dividen. Berbagai penelitian terkait hubungan antara faktor ekonomi makro dan mikro dengan hasil yang berbeda, memperkuat argumentasi interaksinya terhadap risiko investasi. Penelitian

Pola hubungan antara tingkat suku bunga terhadap risiko investasi sesuai dengan penelitian yang dilakukan oleh Makaryanawati dan Ulum (2011), Rahmadani (2012), Yanti (2015), Aprianti (2016) serta Pramana dan Badera (2017) yang menemukan hasil tingkat suku bunga berpengaruh signifikan terhadap risiko investasi. Interaksi antara komponen faktor ekonomi makro yang lain yaitu nilai tukar terhadap risiko investasi juga dikaji oleh Mustika et al (2015) yang menyatakan bahwa nilai tukar atau kurs ditemukan berpengaruh signifikan terhadap risiko investasi. Hasil ini dikonfirmasi oleh Ismawati (2013), Wijaya (2014), Pramana dan Badera (2017) nilai tukar ditemukan tidak berpengaruh signifikan terhadap risiko investasi

Tidak hanya faktor ekonomi makro, faktor ekonomi mikro juga berpengaruh terhadap risiko investasi. Struktur modal merupakan salah satu faktor ekonomi mikro yang mempengaruhi risiko investasi. Hubungan ini dibuktikan oleh Oktaviana (2014), Pramana dan Badera (2017) yang menemukan struktur modal berpengaruh positif signifikan terhadap risiko investasi.. Ketidakkonsistenan hasil ditemukan dalam penelitian Andrianik (2013) bahwa terdapat hubungan negatif signifikan antara sturktur modal terhadap risiko investasi. Deswira (2013) yaitu struktur modal yang diproksikan dengan long term debt to equity tidak memiliki pengaruh yang signifikan terhadap risiko investasi saham. Espireh (2013) dalam penelitiannya di Bursa Efek Teheran juga menemukan tidak ada pengaruh signifikan antara struktur modal yang diproksikan dengan long term debt to equity terhadap risiko investasi saham.

Faktor lain selain struktur modal yaitu likuiditas. Likuiditas dibuktikan berpengaruh positif signifikan terhadap risiko investasi dalam penelitian Nugraha (2011), Rahmadani (2012), Yanti (2015) dan Diana (2014). Ketidakkonsistenan hasil ditemukan pada penelitian Nugraha (2011), Deswira (2013), Pramana dan Badera (2017) ditemukan bahwa likuiditas perusahaan tidak berpengaruh signifikan terhadap risiko investasi.

Berdasarkan fenomena dan perbedaan hasil dari penelitian sebelumnya, maka permasalahan yang diuji dalam penelitian ini adalah apakah faktor ekonomi makro dan mikro berpengaruh terhadap risiko investasi. Hasil dari penelitian ini diharapkan berguna bagi pihak-pihak yang tertaik dengan kajian serupa.

\section{B. TINJAUAN PUSTAKA \\ 1. Risiko Investasi}

Risiko merupakan bagian yang tidak dapat dipisahkan dari Investasi. Secara sederhana, Brigham and Houston (2014) menjelaskan bahwa risiko merupakan berbagai probabilitas terjadinya kondisi yang kurang mengguntungkan. Perbedaan antara yang diharapkan dengan yang diterima, merupakan bagian dari risiko. Risiko investasi merupakan kondisi dimana 
tidak tercapainya return (tingkat keuntungan) yang diharapkan atau terjadinya pernyimpangan antara harapan atas return yang diterima dengan kenyataannya (Jogiyanto, 2012)

Apabila dikaitkan dengan investasi, investasi dapat dibedakan menjadi investasi jangka pendek (secure investment) dan investasi jangka panjang (unsecure investment). Risiko jangka pendek dapat berupa instrumen pasar uang. Risiko jangka panjang berupa investasi pada instrumen pasar modal seperti saham dan obligasi. Risiko merupakan bagian yang tidak dapat dipisahkan dari suatu investasi. Sesuai dengan hukum "high risk high return" investor akan mensyaratkan tingkat keuntungan tertentu pada tingkat risiko tertentu pada suatu investasi (Yanti, 2015).

Menurut Jogiyanto (2012) risiko Investasi diklasifikasikan menjadi risiko yang tidak dapat dihilangkan dengan diversifikasi (risiko pasar dan risiko umum atau risiko sistematis) dan risiko yang dapat dihilangkan melalui diversifikasi (risiko perusahaan atau unsystematic risk). Terdapat beberapa faktor yang berpengaruh terhadap risiko. Risiko Sistematis dipengaruhi oleh kondisi ekonomi, tingkat bunga, tingkat inflasi, kurs valuta asing (nilai tukar) dan kebijakan pemerintah di bidang ekonomi.

\section{Tingkat Suku Bunga}

Tingkat suku bunga menjadi pertimbangan bagi pengambil keputusan pada perusahaan dan investor. Investor saham mengharapkan hasil investasi yang lebih besar. Investor menjadikan tingkat suku bunga sebagai setandar pertimbangan dalam pengambilan keputusan investasi. Apabila tingkat suku bunga tinggi maka investor akan menyimpan dananya di bank, sementara jika tingkat suku bunga turun maka investor akan memilih investasi saham. Bagi perusahaan tingkat suku bunga menjadi bahan pertimbangan dalam menentukan investasi pada proyek baru atau perluasan usaha dengan berbagai kemungkinan risiko yang akan dihadapi (Puspopranoto, 2010)

Sertifikat Bank Indonesia (SBI) adalah surat berharga dalam rupiah yang diterbitkan Bank Indonesia sebagai pengakuan utang berjangka waktu pendek yang diperjualbelikan dengan sistem diskonto. Kenaikan suku bunga SBI dapat mendorong harga saham ke bawah. Kenaikan suku bunga akan meningkatkan beban bunga emiten, sehingga perolehan laba menurun. Selain itu, pada saat suku bunga tinggi, biaya produksi meningkat, harga produk menjadi lebih mahal, dan konsumen akan menunda pembelian, akibatnya penjualan perusahaan menurun. Penurunan penjualan dan penurunan laba ini akan menekan harga saham sehingga mempengaruhi risiko investasi saham.

Makaryanawati dan Ulum (2011) menemukan hasil tingkat suku bunga berpengaruh signifikan terhadap risiko investasi. Secara spesifik pada hasil penelitian Rahmadani (2012) dijelaskan tingkat suku bunga berpengaruh positif dan signifikan terhadap risiko investasi saham pada perusahaan yang terdaftar pada Jakarta Islamic Index. Riantani (2013) juga menemukan hasil yang sama yaitu tingkat suku bunga bepengaruh positif signifikan terhadap risiko investasi. Pola arah berbeda ditemukan dalam penelitian Yanti (2015) dan Aprianti (2016) dimana tingkat suku bunga memiliki pola negatif signifikan terhadap risiko investasi. Pramana dan Badera (2017) juga menemukan bahwa tingkat suku bunga berpengaruh negatif signifikan terhadap risiko investasi.

Berdasarkan kajian diatas, maka hipotesis pertama yang berlaku pada penelitian ini adalah: $\mathrm{H}_{1}$ : Tingkat suku bunga berpengaruh signifikan terhadap Risiko Investasi

\section{Nilai Tukar}

Nilai tukar rupiah adalah harga terhadap mata uang Negara lain hubungan nilai tukar mata uang ini dinyatakan dalam hubungan harga antara lain mata uang tersebut dan hal ini tergantung dari permintaan dan penawaran antar kedua valuta asing yang bersangkutan. Menurunnya kurs akan meningkatkan biaya impor bahan baku dan peralatan yang dibutuhkan oleh perusahaan sehingga akan meningkatkan biaya produksi dan akan menurunkan laba 
perusahaan, sehingga pada akhirnya akan menurunkan profitabilitas perusahaan. Hal ini tentunya akan berdampak terhadap menurunnya harga pasar saham yang diperdagangkan dan meningkatnya risiko terhadap investasi. Nilai tukar atau lazim disebut kurs juga ditegaskan berpengaruh signifikan terhadap risiko investasi (Mustika et al, 2015). Hubungan yang lebih khusus diklarifikasi oleh Yanti (2015 dan Aprianti (2016) yang menemukan nilai tukar rupiah terhadap dollar Amerika berpengaruh negatif terhadap risiko investasi saham.

Berdasarkan kajian diatas, maka hipotesis kedua yang berlaku pada penelitian ini adalah:

$\mathrm{H}_{2} \quad$ : Nilai Tukar berpengaruh signifikan terhadap Risiko Investasi

\section{Struktur Modal}

Pada kondisi semua dana digunakan untuk mendanai aktiva perusahaan berasal dari pemilik dalam bentuk saham biasa, perusahaan tidak terikat pada kewajiban tetap berupa bunga. Bunga adalah biaya tetap keuangan yang harus dibayar dan ditambahkan pada biaya tetap keuangan yang harus dibayar. Jadi, suatu perusahaan yang menggunakan utang dalam berinvestasi akan lebih berisiko dari pada perusahaan tanpa utang, karena selain mempunyai risiko bisnis, perusahaan yang menggunakan utang mempunyai risiko keuangan (Arifin, 2012). Perusahaan yang menggunakan utang jangka panjang dalam jumlah besar mempunyai risiko kegagalan yang lebih besar dibandingkan dengan perusahaan yang menggunakan utang jangka panjang yang lebih kecil. Beban bunga yang harus ditanggung oleh perusahaan akan mengurangi jumlah laba yang tersedia bagi pemegang saham sehingga risiko bagi pemegang saham akan meningkat (Brigham and Daves). Kajian terkait korelasi antara struktur modal dan risiko investasi dilakukan oleh Oktaviana (2014), Diana (2014), Aprianti (2016) Pramana dan Badera 2017) menemukan hasil terdapat pola pengaruh positif signifikan antara struktur modal dan risiko investasi. Ketidakkonsistenan hasil ditemukan dalam penelitian Andrianik (2013) bahwa terdapat hubungan negatif signifikan antara sturktur modal terhadap risiko investasi

Berdasarkan kajian diatas, maka hipotesis ketiga yang berlaku pada penelitian ini adalah:

$\mathrm{H}_{3} \quad$ : Struktur Modal berpengaruh signifikan terhadap Risiko Investasi

\section{Likuiditas Perusahaan}

Likuditas perusahaan merupakan salah satu tolak ukur kemampuan perusahaan dalam memenuhi kewajiban (hutang) jangka pendek yang dimiliki. Semakin tinggi tingkat likuditas maka semakin kecil risiko kegagalan perusahaan dalam memenuhi kewajiban-kewajiban jangka pendek. (Brigham and Houston, 2014). Secara empiris hubungan antara likuditas perusahaan dan risiko investasi diteliti oleh Rahmadani (2012) menemukan tingkat likuiditas perusahaan yang diproksikan dengan current ratio berpengaruh positif dan signifikan terhadap risiko investasi saham pada perusahaan yang terdaftar pada Jakarta Islamic Index. Penelitian Yanti (2015) menemukan hasil terdapat pengaruh positif dan signifikan antara likuiditas perusahaan yang diproksikan dengan current ratio terhadap risiko investasi saham. Hasil berbeda ditemukan Aprianti (2016) yang menemukan bahwa tidak ada pengaruh signifkan antara likuiditas perusahaan terhadap risiko investasi saham.

Berdasarkan kajian diatas, maka hipotesis keempat yang berlaku pada penelitian ini adalah: $\mathrm{H}_{3} \quad$ : Likuiditas berpengaruh signifikan terhadap Risiko Investasi

\section{METODE PENELITIAN}

Penelitian ini termasuk dalam explanatory research dengan pendekatan kuantitatif. Populasi penelitian ini adalah keseluruhan emiten (perusahaan) industri pertanian periode 2014-2018 yang terdaftar di Bursa Efek Indonesia (BEI). Jumlah populasi sebanyak 21 emiten perusahaan industri pertanian. Sampel dalam penelitian ini sebanyak 16 perusahaan 
yang ditentukan dengan metode purposive sampling. Obyek dalam penelitian ini adalah laporan keuangan perusahaan industri pertanian.

Penelitian ini mempergunakan data sekunder, yaitu data yang dikumpulkan oleh pihak lain, peneliti hanya mempergunakan atau menganalisis data tersebut. Sugiyono (2016) menjelaskan data sekunder merupakan data dalam bentuk angka atau data jenis kualitatif yang dikuantitaifkan atau dirubah menjadi angka. Pada penelitian ini daya yang digunakan adalah data sekunder berupa laopran keuangan perusahaan sampel yang diakses melalui resmi www.idx.co.id dan Indonesian Capital Market Directory (ICMD).

Adapun variabel dalam penelitian ini adalah :

1. Variabel bebas (Independent Variable)

Yang termasuk dalam variable bebas pada penelitian ini adalah:

a. Faktor Ekonomi Makro, terdiri dari

$\mathrm{X}_{1}$ : Tingkat Suku Bunga diproksikan dengan tingkat suku bunga SBI sebagai tingkat kenaikan bunga bebas risiko. SBI dalam penelitian ini adalah SBI tahunan periode 2014-2018

$\mathrm{X}_{2}$ : Nilai Tukar Rupiah terhadap Dollar Amerika, Diproksikan dengan kurs tengah tahunan, yaitu rata-rata antara kurs jual dan kurs beli periode 2014-2018

\section{b. Faktor Ekonomi Mikro}

$\mathrm{X}_{3}$ : Struktur Modal, diproksikan dengan long term debt to equity (LTDER) pada industri pertanian di Bursa Efek Indonesia periode tahun 2014-2018

$\mathrm{X}_{4}$ : Likuditas perusahaan, diproksikan dengan current ratio $(C R)$ pada industri pertanian di Bursa Efek Indonesia periode tahun 2014-2018

\section{Variabel Terikat (Dependent Variable)}

Yang termasuk dalam variable bebas pada penelitian ini adalah Risiko Investasi Saham $\left(\mathrm{Y}_{1}\right)$, diproksikan dengan variansa tau standar deviasi dari tingkat pendapatan saham pada perusahaan industri pertanian.

Teknik analisis data yang digunakan dalam penelitian ini adalah analisis regresi linier berganda. Pengujian asumsi klasik merupakan bagian yang tidak dapat dipisahkan dalam analisis ini terdiri dari (uji multikolinieritas, uji heteroskedastisitas, uji normalitas) dengan tujuan analisis regresi linier berganda memberikan manfaat dengan benar (Ghozali, 2013 : 143). Analisis ini bertujuan untuk menguji hubungan antara variabel terikat (Y) dan variabel bebas (X). Sugiyono (2012 : 277) yaitu tingkat suku bunga, nilai tukar rupiah terhadap dollar amerika, struktur modal dan likuiditas perusahaan terhadap risiko investasi.

\section{HASIL PENELITIAN DAN PEMBAHASAN}

Dari hasil analisis regresi linear berganda dari data primer, diperoleh hasil sebagai berikut:

Tabel 1: Analisis regersi linear berganda

\begin{tabular}{ccccccc}
\hline & & \multicolumn{2}{c}{$\begin{array}{c}\text { Unstandardized } \\
\text { Coefficients }\end{array}$} & $\begin{array}{c}\text { Standardized } \\
\text { Coefficients }\end{array}$ & \multirow{2}{*}{ Sig. } \\
\cline { 2 - 6 } & \multirow{2}{*}{ Model } & $\mathrm{B}$ & Std. Error & Beta & & \\
\hline 1 & (Constant) & 80,610 & 57,750 & & 1,396 &, 167 \\
\hline $\mathrm{X} 1$ & 24,852 & 9,907 &, 337 & 2,509 &, 014 \\
\hline $\mathrm{X} 2$ &,- 018 &, 006 &,- 377 & $-2,801$ &, 006 \\
\hline $\mathrm{X} 3$ &, 345 &, 075 &, 485 & 4,627 &, 000 \\
\hline $\mathrm{X} 4$ &,- 028 &, 042 &,- 069 &,- 663 &, 509 \\
\hline
\end{tabular}

a. Dependent Variable: $Y$

Sumber: Data Primer diolah, 2018 


\section{Pengaruh Tingkat Suku Bunga terhadap Risiko Investasi Saham}

Dari tabel 1 (satu) diatas tampak bahwa nilai signifikansi variable $\mathrm{X}_{1}$ sebesar $0,014<$ 0,05. Hal ini menunjukkan terdapat pengaruh positif dan signifikan pada korelasi tingkat suku bunga terhadap risiko investasi saham. Temuan ini bermakna tingkat suku bunga menjadi ukuran investor untuk melakukan pembelian saham pertanian di Bursa Efek Indonesia dengan segala risiko yang menyertainya. Nilai positif menjelaskan apabila tingkat suku bunga meningkat akan diikuti oleh meningkatnya risiko investasi saham. Hal ini disebabkan karena walaupun risiko yang diakibatkan lebih besar dengan kenaikan tingkat suku bunga, namun para investor tetap melakukan investasi saham untuk mengejar tingkat pengembalian yang lebih tinggi. Hasil penelitian ini sejalan dengan penelitian Rahmadani (2012) dan Riantani (2013) yaitu tingkat suku bunga bepengaruh positif signifikan terhadap risiko investasi saham.

\section{Pengaruh Nilai Tukar Rupiah pada Dollar Amerika terhadap Risiko Investasi Saham}

Dari tabel 1 (satu) diatas tampak bahwa nilai signifikansi variable $\mathrm{X}_{2}$ sebesar 0,006 < 0,05, menunjukkan ada pengaruh yang negatif dan signifikan antara nilai tukar rupiah pada dolar Amerika Serikat terhadap risiko investasi saham. Hal ini bermakna bahwa nilai tukar rupiah pada dolar Amerika Serikat menjadi tolak ukur investor dalam melakukan pembelian saham perusahaan Industri Pertanian di Bursa Efek Indonesia dengan segala risiko yang menyertainya. Nilai negatif menjelaskan apabila nilai tukar rupiah pada dolar Amerika Serikat meningkat akan diikuti oleh menurunnya risiko investasi saham. Hasil penelitian konsisten dengan penelitian terdahulu yang dilakukan oleh Yanti (2015) dan Aprianti (2016) yang menemukan nilai tukar rupiah terhadap Dollar Amerika berpengaruh negatif terhadap risiko investasi saham.

\section{Pengaruh Struktur Modal terhadap Risiko Investasi Saham}

Dari tabel 1 (satu) diatas tampak bahwa nilai signifikansi variable $\mathrm{X}_{3}$ sebesar $0,000<$ 0,05 , menunjukkan ada pengaruh yang positif dan signifikan antara struktur modal terhadap risiko investasi saham. Hasil ini dapat dijelaskan maknanya apabila struktur modal meningkat maka akan diikuti oleh meningkatnya risiko investasi saham. Tingkat long term debt to equity yang tinggi menunjukkan komposisi total utang jangka panjang semakin besar apabila dibandingkan dengan total modal sendiri, sehingga hal ini akan berdampak pada semakin besar pula beban perusahaan terhadap pihak eksternal (para kreditur). Semakin besar beban perusahaan maka semakin tinggi tingkat risiko perusahaan tersebut. Pola korelasi ini sejalan dengan penelitian yang dilakukan Oktaviana (2014), Diana (2014), Aprianti (2016), Pramana dan Badera 2017 yaitu struktur modal berpengaruh positif signifikan terhadap risiko investasi saham.

\section{Pengaruh Likuiditas Perusahaan terhadap Risiko Investasi Saham}

Dari tabel 1 (satu) diatas tampak bahwa nilai signifikansi variable $\mathrm{X}_{4}$ sebesar 0,509 > 0,05), menunjukkan ada pengaruh yang negatif dan tidak signifikan antara likuiditas perusahaan terhadap risiko investasi saham. Peningkatan likuditas perusahaan tidak berpengaruh terhadap risiko Investasi saham. Hasil ini menunjukkan bahwa investor dalam menilai risiko investasi saham tidak dicermati dari likuditas perusahaan. Likuiditas perusahaan dianggap tidak terlalu mencerminkan risiko investasi secara nyata. Temuan ini konsisten dengan hasil penelitian Aprianti (2016) yang menemukan bahwa tidak ada pengaruh signifkan antara likuiditas perusahaan terhadap risiko investasi saham.

\section{E. PENUTUP}

Berdasarkan hasil penelitian dapat disimpulkan bahwa faktor ekonomi makro, secara spesifik yaitu tingkat suku bunga ditemukan berpengaruh positif siginifikan terhadap risiko investasi saham. Faktor makro lain yang dikaji dalam penelitian ini yaitu nilai tukar (rupiah terhadap dollar Amerika) dtemukan berpengaruh negatif dan signifikan terhadap risiko 
investasi. Sedangkan untuk faktor ekonomi mikro dalam penelitian ini yaitu struktur modal dan likuditas perusahaan. Ditemukan hubungan likuditas berpengaruh positif dan signifikan terhadap risiko investasi. Pola yang berbeda terdapat pada pengaruh likuditas perusahaan terhadap risiko investasi yaitu negatif tidak signifikan.

Berdasarkan simpulan diatas, disarankan kepada investor hendaknya memperhatikan faktorfaktor ekonomi seperti struktur modal, likuiditas, suku bunga dan nilai tukar dalam keputusan investasi di Industri Pertanian di Bursa Efek Indonesia. Pemerintah juga diharapkan dapat mempertahankan stabilitas ekonomi dengan tingkat pertumbuhan yang tinggi, dan lebih berperan dalam proses deregulasi moneter dalam kebijakan menaikkan ataupun menurunkan suku bunga dan meningkatkan nilai tukar sehingga iklim investasi yang kondusif tetap dapat terwujud.

Bagi peneliti selanjutnya yang tertarik meneliti tentang kajian sejenis, diharapkan meneliti faktor ekonomi lainnya seperti ukuran perusahaan dan Inflasi. Ukuran perusahan yang semakin besar maka mencerminkan semakin tinggi tingkat risiko yang dihadapi investor, sedangkan Inflasi merupakan indikator tingkat pencapaian ekonomi suatu negara adalah tingkat inflasi. Semakin tinggi inflasi makan semakin rendah tingkat pendanaaan dari luar investor karena semua peningkatan harga atas suber daya.

\section{DAFTAR PUSTAKA}

Arifin, Ali. 2012. Membaca Saham Panduan Dasar Seni Berinvestasi dan Teori Permainan Saham, Penerbit Andi, Yogyakarta.

Andrianik. 2013. Analisis Faktor-Faktor yang Mempengaruhi Resiko Investasi Saham pada Perusahaan Farmasi yang Go Public di Bursa Efek Indonesia, Jurnal Fakultas Ekonomi Jurusan Akuntansi Universitas Gunadarma Jakarta.

Aprianti, Ni Nyoman Ayu Tyas. 2016. Analisis Faktor-faktor yang Mempengaruhi Risiko Investasi Saham pada Industri Otomotif dan Komponen di Bursa Efek Indonesia, Skripsi Jurusan Akuntansi Fakultas Ekonomi Universitas Warmadewa Denpasar.

Atmadja, A. T., \& Saputra, K. A. K. (2018). Determinant Factors Influencing the Accountability of Village Financial Management. Academy of Strategic Management Journal. Vol. 17. Issue 1.

Atmadja, A. T., Saputra, K. A. K., \& Koswara, M. K. (2018). The Influence Of Village Conflict, Village Apparatus Ability, Village Facilitator Competency And Commitment Of Local Government On The Success Of Budget Management. Academy of Accounting and Financial Studies Journal, 22(1), 1-11.

Brigham, Eugene F and Joel F. Houston. 2014. Fundamentals of Financial Management, 14th Edition. Mason : South-Western Cengange Learning

Deswira, Tita. 2013. Pengaruh Likuiditas, Struktur Modal dan Ukuran Perusahaan terhadap Risiko Investasi Saham yang terdaftar di Jakarta Islamic Index. Jurnal Akuntansi. Available at e-journal.unp.ac.id

Diana, Ni Wayan Arisma Gangga Putri. 2014. Analisis Faktor-faktor yang Mempengaruhi Risiko Investasi Saham pada Industri Telekomunikasi yang Go Public di PT Bursa efek indonesia, Jurnal Jurusan Akuntansi Fakultas Ekonomi Universitas Warmadewa Denpasar.

Ghozali, Imam. 2013. Aplikasi Analisis Multivariat dengan Program IBM SPSS 21, Badan Penerbit Universitas Diponegoro, Semarang.

Ismawati, Linna. 2013. Pengaruh Kurs Mata Uang RUpiah atas Dollar AS, Tingkat Suku Bunga Sertifikat Bank Indonesia dan Tingkat Inflasi terhadap Indeks Harga Saham Gabungan (IHSG) pada Bursa Efek Indonesia (BEI). Jurnal Ekono Insentif Kopwil, 7 (2) :1-13

Jogiyanto, (2012), Teori Portofolio dan Analisa Investasi, Penerbit BPFE, Yogyakarta. 
Markaryanawati dan Misbachul Ulum. 2011. Pengaruh Tingkat Suku Bunga dan Tingkat Likuditas Perusahaan terhadap Risiko Investasi Saham yang Terdaftar pada Jakarta Islamic Index. Jurnal Ekonomi Bisnis, 14 (1) : 49-60

Mustika, Candra., Umiyati, Etik dan Achmad, Erni. 2015. Analisis Pengaruh Ekspor Neto terhadap Nilai Tukar Rupiah terhadap Dolar Amerika Serikat dan Pertumbuhan Ekonomi di Indonesia. Jurnal Paradigma Ekonomika, Vol.10, No.2.

Nugraha, I Gede Budi. 2011. Analisis Faktor-Faktor yang Mempengaruhi Risiko Investasi Saham pada Industri Farmasi yang Go Public di PT.Bursa Efek Indonesia. Skripsi. Fakultas Ekonomi Jurusan Akuntansi Universitas Udayana Denpasar.

Pramana, I. B. Nyoman dan Badera, I Dewa Nyoman. 2017 Faktor-Faktor yang Mempengaruhi Risiko Investasi Saham. E-jurnal Akuntansi Universitas Udayana Vol.18.3. Maret 2017 : 1860-1887

Puspopranoto, Sawaldjo. 2010. Keuangan Perbankan dan Pasar Keuangan (Konsep, Teori dan Realita). Jakarta : Pustaka LP3ES Indonesia

Rahmadani, Rochmad Furi. 2012. Pengaruh Tingkat Suku Bunga dan Tingkat Likuiditas Perusahaan terhadap Risiko Investasi Saham yang terdaftar pada Jakarta Islamic Index (JII) 2009-2010. Jurnal Fakultas Ekonomi dan Bisnis Universitas Dian Nuswantoro Semarang : $1-15$

Rizal, M. 2016. Analisis Pengaruh Profitabilitas dan Likuiditas terhadap Return Saham Syariah dengan Risiko Investasi sebagai Variabel Intervening (Studi Empiris pada.

Rrepository.unej.ac.id

Saputra, K. A. K., Anggiriawan, P. B., \& Sutapa, I. N. (2018). Akuntabilitas Pengelolaan Keuangan Desa Dalam Perspektif Budaya Tri Hita Karana. Jurnal Riset Akuntansi Dan Bisnis Airlangga, 3(1).

Sugiyono, (2016), Metode Penelitian Bisnis, Penerbit Alfabeta, Bandung.

Deswira, Tita. 2013. Pengaruh Likuiditas, Struktur Modal dan Ukuran Perusahaan Terhadap Risiko Investasi Saham yang Terdaftar di Jakarta Islamic Index, Jurnal Fakultas Ekonomi Universitas Negeri Padang: 1-15.

Wijaya, Trisnadi. 2014. Analisis Pengaruh Tingkat Inflasi, Tingkat Suku Bunga SBI dan Nilai Tukar Rupiah terhadap Indeks Harga Saham Gabungan (IHSG) di Bursa Efek Indonesia. Jurnal STIE MDP, 8 (3) : 1-8

Yanti, Ni Putu Ayu Dewi, (2015), Analisis Faktor-faktor yang Mempengaruhi Risiko Investasi Saham pada Perusahaan Telekomunikasi, Jurnal Fakultas Ekonomi dan Bisnis Universitas Udayana (Unud), Bali. 